Our Nature (2005)3:91-93

\title{
First Ever Large Scale Botanical Training
}

\author{
Kamal Maden \\ DarwinScholar, sitakamal@wlink.com.np
}

Nepal provides unique opportunities to naturalists for studying nature. It connects the floristically distinct eastern and western Himalayan regions and is of high botanical interest because of both its phytogeographical linkages and its floral wealth (Rajbhandari, 2002). About 55 years ago, there was no knowledge on the flora and phytogeography of Nepal, but due to research carried out on the Nepalese flora since then, it is known botanically to considerable degree.

At first, scientific records of Nepalese plants appeared long before in 1825 when David Don published Prodromus Florae Nepalensis, and Nathanial Wallich's Tentamen Florae Nepalensis published from 1824 to 1826 and Plantae Asiaticae Rariores published in 1830. Recently published Annotated Checklist of the Flowering Plants of Nepal edited by Press et. al (2000) contains a list of 216 families, 1534 genera, 5345 species, 163 subspecies, 517 varieties, and 51 formae of flowering plants of Nepal.

For the Nepalese plants to materialize, it has been realized that it has to be a collaborative project and in 2003 an agreement has been signed between the Royal Nepal Academy of Science and Technology (RONAST) and Royal Botanical Garden Scotland (RBGE), United
Kingdom (UK) in collaboration with Department of Plant Resources (DPR) and Central Department of Botany, Tribhuvan University (CDBTU). To enhance the botanical research in Nepal, RBGE organized a three-year Darwin Initiative training project (2004-2006) in collaboration with RONAST. Major objectives of the project include skill and capacity strengthening of Nepalese botanists and institutions especially in the fields of Plant Biodiversity, Inventory and Conservation.

The project has been coordinated and assisted by RBGE experts Dr Mark Watson, Mr Tony Miller, Mr David Knott, Dr Crinan Alexander and Dr Colin Pendry respectively and three Nepalese coordinators from three different institutions namely, Dr K. R. Rajbhandari (DPR), Prof Dr K. K. Shrestha (CDBTU) and Dr Kayo Devi Yami (RONAST). Sixteen botanists have been selected as Darwin Scholars to be trained by the British as well as Nepalese botanists. The trainees are chosen on the basis of their taxonomic research background, geographical area of their work and their affiliated sectors or and institutions with such as Tribhuvan University, Governmental Agencies and freela-ncers.

Each Darwin Scholar has to specialize in particular plant groups and 
prepares a personal project account in the designated Flora of Nepal format of 2005. The Scholars have already participated three training workshop and three collecting expeditions in Nepal as a part of the training project. They also observed herbarium specimens of their own groups at the Royal Botanical Garden, Godavari, Lalitpur (KATH) and the UK, the world's most renowned botanical gardens. In 2005, eight Darwin Scholars including one Nepalese coordinator Dr Rajbhandari undertook a research visit to the RBGE, Natural History Museum, London (BM) and Royal Botanic Gardens, Kew, London (K). The scholars have published a paper entitled Plant Collection \& Herbarium Techniques (Maden 2005) and a booklet $A$ report on the UK visit by Darwin Scholars in 2005. The remaining Darwin scholars will do the same research visit to the botanical institutes in the UK in January-February 2006, accompanied by Prof. Dr. Shrestha.

During the UK research visit, the Darwin scholars acquired general experiences in the management and operation of renowned international herbaria. The scholars obtained more specific experiences in the activities and research undertaken at RBGE regarding use of living collections. They developed identification skills by working on the specimens collected during the expeditions. Moreover, they participated in one-to-one tutorage by RBGE staff on their individual projects and use the herbarium and library resources at the three major UK botanical institutes.
Two of the three training expeditions in Nepal were located in Sagarmatha National Park in the Mount Everest region and one in Chitwan National Park. The first Sagarmatha National Park expedition collected 368 collections, including 328 herbarium collections in sets of six: Angiosperms 311, Gymnosperms 8, Pteridophytes 9 (Rajbhandari et. al 2004). The expeditions were well provided with advanced equipments especially global positioning systems (GPS) to record the exact location and altitude of each specimen, digital cameras to take photos, laptop computers to record ecological notes about each plant, etc. During the expeditions, six sets of specimens were gathered for each collection. The first good quality specimen is for the KATH, second for the CDBTU, herbarium section (TUCH), and third for the collected areas authority and the remaining all for the UK's institutes.

The Scholars have to follow scientific procedures of collecting and drying techniques for each specimen. High priority is to be given to preparing good specimens. So, healthy flowering or fruiting specimens are given importance. Silica gel is used to preserve leaf fragments for DNA analysis. Soon after the plant sample is collected it is pressed in newspaper and placed in a field press. Back at the camp the newspaper containing plant specimens are put between blotting papers. Between the blotting papers aluminum corrugated sheets are put and a bundle is made. These bundles are tied by straps with wooden press frame at both ends. These 
bundles are put on a metal stand (drying frame) above a kerosene stove with mild he-at. While heating, the whole unit (i.e. drying frame, stoves and plant bundle, except the upper portion of the bundle) is surrounded by a fireproof mountain survival blanket. Heating continues until the plant specimens are well dried, usually within 12 hours.

During the day the Scholars have to keep detailed field notes for the collections and in the evening at camp they have to enter the field notes on the laptop computers. The field notes includes following information: collection number of the specimen, name of plant (provisional field name), date, locality, longitude, latitude, altitude, habitat, vegetation type and associated species, habitat and frequency indicator (dominant, abundant, frequent, occasional or rare: DAFOR scale).

The Scholars have completed all three training workshops in Kathmandu namely, 'Building Capacity for Biodiversity Inventory and Conservation in Nepal' (18 March- 2 April 2004), 'Biodiversity Documentation, Conservation Assessment and Flora Writing Skill' (211 November 2004) and $3^{\text {rd }}$ training workshop 'Herbarium Collection, Management and Documentation' (23 November-5 December 2005). The training workshops were mostly held at British Embassy, Kindon Hall, Lainchaur, Kathmandu.

The third or final training workshop was conducted mainly by three key trainers from the RBGE, Dr Mark F. Watson, Dr Colin Pendry and Dr Elspeth
Haston; and 3 associated trainers from Nepal namely, Dr K .R. Rajbhandari, Prof Dr K. K. Shrestha, and Dr Mohan Siwakoti (Natural History Museum,TU). Guest speakers included: Dr Linda Whittaker (Ecologist), Dr Brain J. Penniston (Coordinator, TMI), Dr C. Fraser Jenkins (Ferns and Allies expert of Eastern Himalaya), Dr U. R. Sharma (Ministry of Forest), Dr K.C. Paudel (Ministry of Forest and Soil Conservation), Mr S. Tiwari (Acting Courty Representative, IUCN Nepal), Dr M. K. Adhikari (Chief, KATH), Dr. M. Devakota (TU), Dr. S. Ghimire (TU) and Ms N. Pradhan (Natural History Museum, TU). During the $3^{\text {rd }}$ training workshop all the trainers and trainees undertook one day field trip to Hattiban, Kathmandu. For this the trainees were divided into 4 groups with one expert. The groups successfully did the assignment of collecting, making herbarium press and documentation of the specimens especially lichens, mosses, ferns and flowering plants. Besides, they have also collected specimens in silica gel.

One of the project objectives is to strengthen skill and capacity of Nepalese institutions. The RBGE experts presented two binocular dissecting microscopes, 4 GPS units, various herbarium tools and sets of Flora of China to KATH and CDBTU. Not only the technologically advanced equipments but also valuable literary references, which greatly help botanists, foresters, agriculturists, horticulturists and social science researches. 
K. Maden/ Our Nature (2005)3:91-95

The Darwin Initiative Project will be concluding in October 2006. Soon afterwards, RBGE in collaboration with the Nepalese institutions is planning to implement a new and most urgently needed project, called Flora of Nepal (www.floraofnepal.org). This will be the first complete detailed official record of the plants Nepal. The timespan of this gargantuan work will be more or less 15 years. For this work all past and present specimens collected from Nepal will be studied and added as new additional collection from different part of nation's countryside.

Hopefully, this long awaited project will be implemented as planned, and will become one of the greatest accomplishments for not only Nepalese botanists and conservationists but also for the people of Nepal in protecting and maintaining the nation's plant resources.

\section{Acknowledgements}

I am thankful to Darwin Initiative Project, UK for providing opportunity to be involved in the three year training as a Darwin Scholar.

\section{Reference}

Maden, K. 2005. Plant Collection \& Herbarium Techniques. Our Nature, Vol.2 (2):53-57. Nature Conserv. \& Health Care Council, Biratnagar, Nepal.

Press, J.R., K. K. Shresth and D.A. Sutton 2000. Annotated Checklist of the Flowering Plants of Nepal. The Natural History Museum, London.

Rajbhandari, K.R. 2002. Flora of Nepal: 200 years' march. In: Schichi Noshiro \& Keshab R. Rajbhandari (Eds), Himalayan Botany in the Twentienth and Twenty-first Centuries, The Society of Himalayan Botany Tokyo.

Rajbhandari, K. R., R. Uprety, V. Manandhar, K. Maden \& B. Adhikari 2004. Botanical expedition in the Sagarmatha National Park, east Nepal in 2004. Plant Reso-urces (An Occasional Publication). Department of Plant Resources: 63-67. 
K. Maden/ Our Nature (2005)3:91-95
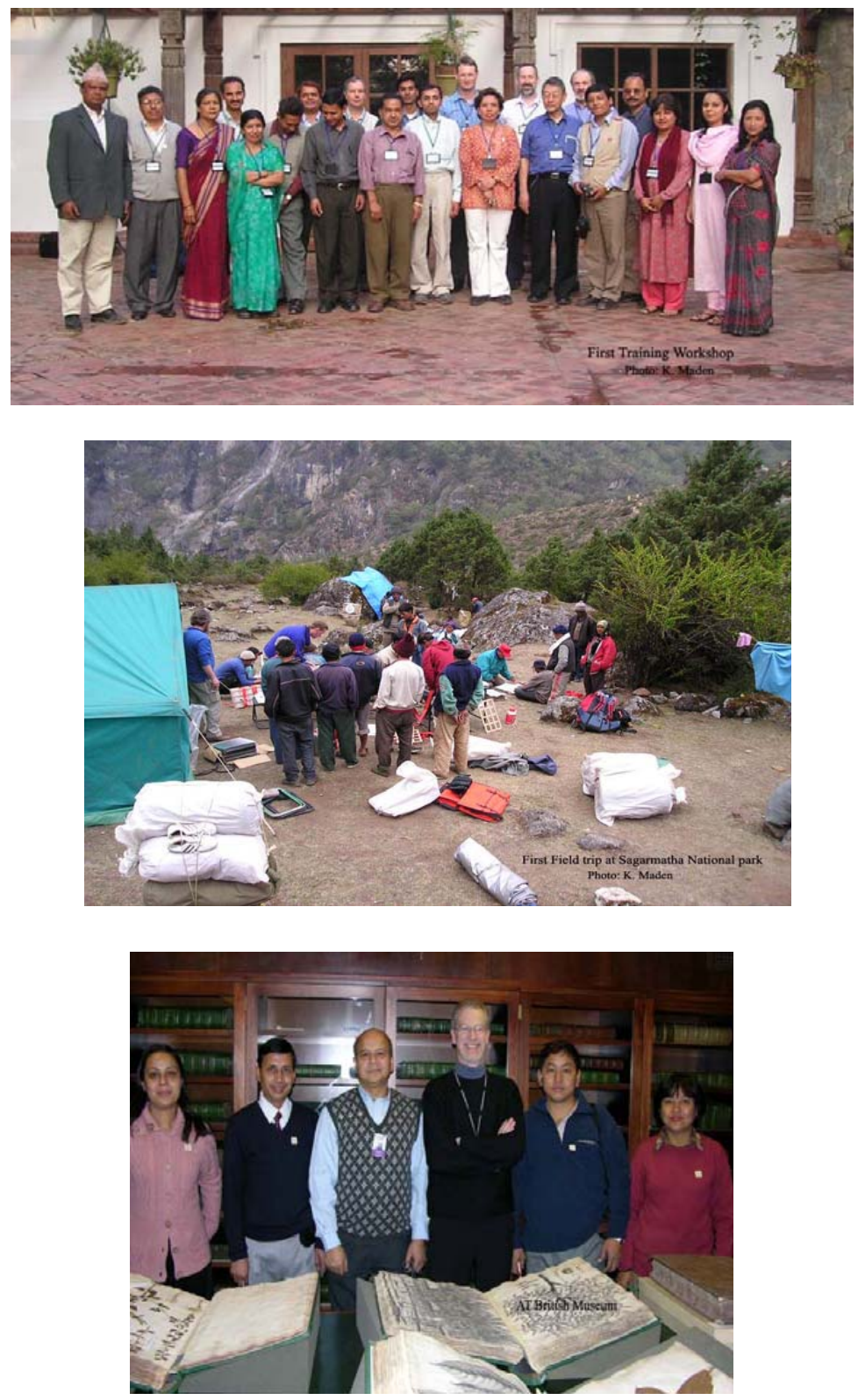